\title{
Smartphones:
}

\section{A Potential Discovery Tool}

The anticipated wide adoption of smartphones by researchers is viewed by the authors as a basis for developing mobile-based services. In response to the UNLV Libraries' strategic plan's focus on experimentation and outreach, the authors investigate the current and potential role of smartphones as a valuable discovery tool for library users.

W hen the dean of libraries announced a Discovery Mini-Conference at the University of Nevada Las Vegas Libraries to be held in spring 2009, we saw the opportunity to investigate the potential use of smartphones as a means of getting information and services to students. Being enthusiastic users of Apple's iPhone, we and the Web technical support manager, developed a presentation highlighting the iPhone's potential value in an academic library setting. Because Wendy is UNLV Libraries' director of user services, she was interested in the applicability of smartphones as a tool for users to more easily discover the libraries' resources and services. Eva, as the health sciences librarian, was aware of a long tradition of PDA use by medical professionals. Indeed, first-year Bachelor of Science Nursing students are required to purchase a PDA bundled with select software. Together we were drawn to the student-outreach possibilities inherent in new smartphone applications such as Twitter, Facebook, and MySpace.

\section{Presentation}

Our brief review of the news and literature about mobile phones in general provided some interesting findings and served as a backdrop for our presentation:

- A total of 77 percent of Internet experts agreed that the mobile phone would be "the primary connection tool" for most people in the world by $2020 .{ }^{1}$ The number of smartphone users is expected to top 100 million by 2013 . There are currently 25 million smartphone users, with sales in North America having grown 69 percent in 2008. ${ }^{2}$

- Smartphones offer a combination of technologies, including GPS tracking, digital cameras, and digital music, as well as more than fifty-thousand specialized apps for the iPhone and new ones being

Wendy Starkweather (wendy.starkweather@unlv.edu) is Director, User Services Division, and Eva Stowers (eva.stowers @ unlv.edu) is Medical/Health Sciences Librarian at the University of Nevada Las Vegas Libraries. designed for the Blackberry and the Palm Pre. ${ }^{3}$ The Palm Pre offered less than twenty applications at its launch, but one million apllication downloads had been performed by June 24, 2009, less than a month after launch. ${ }^{4}$

- The 2009 Horizon Report predicts that the time to adoption of these mobile devices in the educational context will be "one year or less."

Data gathered from campus users also was presented, providing another context. In March 2009, a survey of University of California, Davis (UC-Davis) students showed that 43 percent owned a smartphone. ${ }^{6} \mathrm{UC}$-Davis is participating in Apple's University Education Forum. Here at UNLV, 37 percent of students and 26 percent of faculty and staff own a smartphone. ${ }^{7}$

The presentation itself highlighted the mobile applications that were being developed in several libraries to enhance student research, provide library instruction, and promote library services. Two examples were Abilene Christian University (http://www.acu.edu/technology/ mobilelearning/index.html), which in fall 2008 distributed iPhones and iPod Touches to the incoming freshman class; and Stanford University (http:/ / www.stanford .edu/services/wirelessdevice/iphone/) which participates in "iTunes U" (http://itunes.stanford.edu/). If the Libraries were to move forward with smartphone technologies, it would be following the lead of such universities.

Readers also may be interested in Joan Lippincott's recent concise summary of the implications of mobile technologies for academic libraries as well as the chapter on library mobile initiatives in the July 2008 Library Technology Report. ${ }^{8}$

\section{Goals: A balancing act}

Ultimately the goal for many of these efforts is to be where the users are. This aspiration is spelled out in UNLV Libraries' new strategic plan relating to infrastructure evolution, namely, "Work towards an interface and system architecture that incorporates our resources, internal and external, and allows the user to access from their preferred starting point." ${ }^{\prime \prime}$ While such a goal is laudable and fits very well into the discovery emphasis of the Mini-Conference presentation, we are well aware of the need for further investigation before proceeding directly to full-scale development of a complete suite of mobile services for our users. Of critical importance is ascertaining where our users are and determining whether they want us to be there and in what capacity. The value of this effort is demonstrated in Booth's research report on student interest in emerging technologies at Ohio State University. The report includes the results of an extensive environmental survey of their 
library users. The study is part of Ohio State's effort to actualize their culture of assessment and continuous learning and to use "extant local knowledge of user populations and library goals" to inform "homegrown studies to illuminate contextual nuance and character, customization that can be difficult to achieve when using externally developed survey instruments." 10

UNLV Libraries are attempting to balance early experimentation and more extensive data-driven decision-making. The recently adopted strategic plan includes specific directions associated with both efforts. For experimentation, the direction states, "Encourage staff to experiment with, explore, and share innovative and creative applications of technology."11 To that end, we have begun working with our colleagues to introduce easy, small-scale efforts designed to test the waters of mobile technology use through small pilot projects. "Text-a-Librarian" has been added to our existing group of virtual reference service, and we introduced a "text the call number and record" service to our library's OPAC in July 2009.

UNLV Libraries' strategic plan helps foster the healthy balance by directing library staff to "emphasize data collection and other evidence based approaches needed to assess efficiency and effectiveness of multiple modes and formats of access/ownership" and "collaborate to educate faculty and others regarding ways to incorporate library collections and services into education experiences for students."12 Action items associated with these directions will help the Libraries learn and apply information specific to their users as the Libraries further adopt and integrate mobile technologies into their services.

As we begin our planning in earnest, we look forward to our own set of valuable discoveries.

\section{References}

1. Janna Anderson and Lee Rainie, The Future of the Internet III, Pew Internet \& American Life Project, http:/ / www.pewinternet .org/ /media//Files/Reports/2008/PIP_FutureInternet3.pdf .pdf (accessed July 20, 2009).

2. Sam Churchill, "Smartphone Users: 110M by 2013," blog entry, Mar. 24, 2009, dailywireless.org, http://www.daily wireless.org / 2009/03/24/smartphone-users-100m-by-2013 (accessed July 20, 2009).

3. MG Siegler, "State Of The iPhone Ecosystem: 40 Million Devices and 50,000 Apps," blog entry, June 8, 2009, Tech Crunch, http:/ / www.techcrunch.com/2009/06/08/40-million-iphones -and-ipod-touches-and-50000-apps (accessed July 20, 2009).

4. Jenna Wortham, "Palm App Catalog Hits a Million Downloads," blog entry, June 24, 2009, New York Times Technology, http:/ / bits.blogs.nytimes.com/2009/06/24/palm-app-cataloghits-a-million-downloads (accessed July 20, 2009).

5. Larry Johnson, Alan Levine, and Rachel Smith, Horizon Report, 2009 Edition (Austin, Tex.: The New Media Consortium, 2009), http://www.nmc.org/pdf/2009-Horizon-Report.pdf (accessed July 20, 2009).

6. University of California, Davis. "More than $40 \%$ of Campus Students Own Smartphones, Yearly Tech Survey Says," TechNews, http://technews.ucdavis.edu/news2.cfm?id=1752 (accessed July 20, 2009).

7. University of Nevada Las Vegas, Office of Information Technology, "Student Technology Survey Report: 20082009," http:/ / oit.unlv.edu/sites/default/files/survey/Survey Results2008_Students3_27_09.pdf (accessed July 20, 2009).

8. Joan Lippincott, "Mobile Technologies, Mobile Users: Implications for Academic Libraries," ARL Bi-monthly Report 261 (Dec. 2008), http:/ / www.arl.org/bm doc/arl-br-261-mobile .pdf. (accessed July 20, 2009); Ellyssa Kroski, "Library Mobile Initiatives," Library Technology Reports 44, no. 5 (July 2008): 33-38.

9. “UNLV Libraries Strategic Plan 2009-2011," http://www library.unlv.edu/about/strategic_plan09-11.pdf (accessed July 20, 2009): 2

10. Char Booth, Informing Innovation: Tracking Student Interest in Emerging Library Technologies at Ohio University (Chicago: Association of College and Research Libraries, 2009), http:// www.ala.org/ala/mgrps/divs/acrl/publications/digital/ ii-booth.pdf (accessed July 20, 2009); “UNLV Libraries Strategic Plan 2009-2011," 6.

11. "UNLV Libraries Strategic Plan 2009-2011," 2.

12. Ibid. 